\title{
Patient-Device Interaction Problem
}

National Cancer Institute

\section{Source}

National Cancer Institute. Patient-Device Interaction Problem. NCI Thesaurus. Code C133496.

Problem related to the interaction between the patient and a medical device. 